\title{
AYURLOG
}

National Journal of Research in Ayurved Science

http://www.ayurlog.com

Nov- 2020 | Volume 08 $^{\text {th }} \mid$ Issue: $6^{\text {th }}$

ISSN: 2320-7329

\section{Hypoglycemic activity of Kaidarya Patra Choorna (Murraya koenigii linn.) in Diabetes mellitus type 2 with OHA's}

\author{
Rawate Suraj M.*¹, Kore Sharayu ${ }^{2}$
}

1. P.G. Scholar, Dept. of Dravyaguna, MAM's SSAM Hadapsar, Pune, Maharashtra.

2. Professor, HOD and Guide, Dept. of Dravyaguna, SSAM Hadapsar, Pune, Maharashtra.

\section{*Corresponding Author: Email id - surajrawate149@ gmail.com}

\begin{abstract}
:
Globally and nationally the Diabetes mellitus with its complications become the most important contemporary and challenging health problem. It should be treated with diet and exercise, typically in conjunction with oral hypoglycemic drugs (OHD) and the complications are so critical and hazardous, and oral hypoglycemic agents and insulin which is used for the treatment of diabetes mellitus by the allopathic system of medicine have numerous side effects. In spite of available treatment number of patients is on rise. It is convincing that the herbal or mineral remedies stated in ayurveda used singly or in combination have potency in the treatment of madhumeha. However, our country is indeed rich in its vast variety of flora, throught variegated physical feature of the
\end{abstract}

land, extending from mountains to the oceans. The practitioners of Indian system of medicine have been using the plant materials and are claiming success in treatment of madhumeha even today. Therefore, taking a lead it will be worthwhile to reappraise the commonly used plant remedies in the treatment of madhumeha, with an unbiased scientific spirit. In Ayurveda kaidarya is mentioned as parvata nimba. Nimba is the best drug used in Prameha. Edible variety of Nimba i.e curry leaves can be useful. Kaidarya is having katu, tikta, and kashaya rasa and sheeta veerya. It pacifies vitiated kapha and pitta. Kaidarya has been used traditionally since few years for treatment of prameha. Placebo control may not be ethical in the disease hence single arm study along with modern medicine is preffered. 
Keywords: Diabetes mellitus, kaidarya, Oral Hypoglycemic agents

\section{Introduction:}

Plants have been the major source of drugs in Indian system of medicine and other ancient systems in the world. Earliest description of curative properties of medicinal plants is found in Rig-Veda (2500 -1800 BC). Charka Samhita and Sushruta Samhita give extensive narration on various medicinal herbs. Now in current scenario the use of plant derived natural products in drugs preparations becomes a drift, therefore there is a need to date information on the properties, uses, efficacy, safety of medicinal plant products. Diabetes mellitus is one of the most common chronic disease in the whole world. It is a complex, multifactorial disease, which affects the quality, quantity, and style of a person's life. The fact confirmed by report from the World Health Organization (WHO) shows that India has the largest number of diabetic patients in the world. Many drugs have been used to control hyperglycaemia, but these synthetic agents produce some serious side effects and are relatively costly for developing countries. The toxicity of oral anti-diabetic agents varies widely in clinical expressions, strictness, and treatment. In the natural system of medicine, many plants have been appealed to be useful for the treatment of hyperglycaemia. The dependence of large rural population on medicinal plants for treatment of diabetes is because of its convenience and affordability. Additionally, after the approval made by WHO on diabetes mellitus, the recognition of antidiabetic agent derived from plants become more popular and important. Many plant sps like Dillenia indica, Trigonella foenumgracum and Amaranthus sps etc. have been evaluated for their hypoglycaemic action. Hyperglycaemia is a pathological condition associated with prediabetes and diabetes. The occurrence of prediabetes and diabetes is increasing and carry out great problem on healthcare worldwide. Patients with prediabetes and diabetes have significantly increased risk for cardiovascular diseases and other problems. Presently, management of hyperglycaemia includes pharmacological involvements, physical exercise, and change of life style and diet. Food supplements have increasingly become better alternatives to treat hyper-glycaemia. In a review regarding anti- diabetic herb, five commonly used food supplements with hypoglycaemic effects, including Emblica officinalis (gooseberry), fenugreek, green tea, Momordica charantia (bitter melon) and cinnamon were considered. Fenugreek and Emblica officinalis showed the most consistency in lowering fasting blood sugar (FBS) or glycated hemoglobin (HbA1c) levels in diabetic patients. The hypoglycaemic effects of cinnamon and Momordica charantia were seen the best. However, green tea exhibited inadequate benefits in reducing FBS. In another report, the consumption of cinnamon is connected with a statistically significant decrease in levels of fasting plasma glucose. Murraya koenigii (Family: Rutacea) is a small tree. Curry leaf is found almost throughout India up to an altitude of 1500 meters. It is much cultivated for its aromatic leaves. Kaidarya plant (experimental plant) extracts (methanolic and aqueous) have been 
evaluated for its hypoglycaemic activity in Streptozotocin induced diabetic rat model, so it was highly essential to compare the data of hypoglycaemic activity of Kaidarya (Murraya koenigii linn.) leaves powder with previous results.

Hence, the main goal of the present study to find out the better source to manage the hyper glycaemia. We have evaluated leaves powder of the experimental plant (Murraya koenigii) collected from Pune, Maharashtra region in the month of October for its hypoglycaemic action.

\section{AIM:}

- To evaluate hypoglycemic activitiy of kaidarya patra choorna ( Murraya koenigii Linn.) In Diabetes mellitus type 2 with oral hypoglycemic agent.

\section{Objective:}

- To study ayurvedic perspective of prameha.

- Ellaborative study of Diabetes mellitus

- Detailed study of kaidarya.

- To assess the hypoglycemic activitiy of kaidarya patra choorna in treatment of Diabetes mellitus type 2 .

\section{MATERIAL AND METHODS}

\section{Materials: -}

\section{1) Patients:}

32 patients were selected from indoor and outdoor patients department of the hospital.

\section{2) Drugs:}

- Kaidarya patra choorna

- Tab. Metformin

- Tab. Sulfonyl group.

\section{3) Instrument:}

Weighing machine

\section{4) Preparation of Kaidarya Patra} Choorna:

- According to Sharangdhar Samhita choorna was prepared.

The drugs mentioned in the churna yoga are cleaned and dried. They are powered by pounding with mortar and pestle and sieved through a thin layer of cloth (Vastragalita). In a prescription where there are a number of ingredients, the best method is to powder the drugs separately, weight the required quantities of the drugs and mix them all together.

\section{Dose and time of administration:}

Dose: 2.5 gm of choorna

Time: Twice a day

Kaal: Apankaal (Before meals)

Anupana: Koshnajala

Duration: 90 days.

- Authentication of the drug was done in Botanical survey of India, pune.

- Standardization of the drug was done in Standard Pharmacy. Analytical reports are as follows- 
- Analytical reports of Kaidarya patra chorona.

\begin{tabular}{|l|l|}
\hline PHYSICAL TESTS & RESULT \\
\hline Description & Fine powder \\
\hline Colour & Light greenish \\
\hline Odour & $\begin{array}{l}\text { Characteristically } \\
\text { aromatic }\end{array}$ \\
\hline Taste & Acrid \\
\hline Moisture content & $3.8 \%$ \\
\hline Ash & $14.76 \%$ \\
\hline Acid insoluble Ash & $3.06 \%$ \\
\hline $\begin{array}{l}\text { Alcohol soluble } \\
\text { extracts }\end{array}$ & $10.65 \%$ \\
\hline Water soluble extracts & $26.27 \%$ \\
\hline pH & 5.7 \\
\hline
\end{tabular}

\section{METHODOLOGY:}

1. This was prospective, randomized, controlled, single blind clinical trial.

2. Through history and complaints of the patients were taken. Each and every patient was carefully examined clinically for general and systemic sign and symptoms.

3. Full explanation about the trial was given to each patient and written consent of each patient was taken before the commencement of treatment.

4. After that total 32 patients were selected for present clinical trial on the basis of clinical diagnosis.
5. Randomized method was used for selecting patients in trial or control group and equally divided into two groups as below:-

Trial Group: - In this group, 16 patients of Diabetes Mellitus (Madhumeha) taking oral hypoglycemic drugs maximally two regimes (i.e. Metformin + sulfonyl urea) adviced by allopathic experts with Kaidarya patra choorna.

Control Group: - In this group, 16 patients of Diabetes Mellitus (Madhumeha) taking oral hypoglycemic drugs (Metformin + sulfonyl urea) adviced by allopathic experts.

5) Pathya and Apathya: Trial group and control group were adviced to take standard diabetic diet according to ayurvedic texts and modern medical science.

\section{6) Inclusive Criteria:}

- Age- 30-50 yrs.

- BSL: - fasting upto $200 \mathrm{mg} / \mathrm{dl}$.

Post prandial upto $300 \mathrm{mg} / \mathrm{dl}$.

- Volunteers with Diabetes Mellitus type 2 taking regular medicines.

\section{7) Exclusive Crieteria: -}

- Individuals recently hosptalized or undergone any major surgery (within 3 months)

- Individuals with BSL fasting more than $200 \mathrm{mg} / \mathrm{dl}$ and Post prandial more than $300 \mathrm{mg} / \mathrm{dl}$.

- Pregnant women and lactating mothers.

- Individuals with major systemic illness. E.g. CA, AIDS, TB etc.

- Patients not willing for trial. 
8) Diagnostic Criteria: -

- BSL

- HbA1c (glycated haemoglobin)

- Classical signs and symptoms of Diabetes Mellitus with clinical relevance.

\section{9) Withdrawal Criteria: -}

- During the course of trial if there were any hypo/hyperglycemic episodes or any other serious conditions which urgently requires investigations and treatment.

- Patient him/herself wants to withdraw from clinical trial.

- Those who do not appear for regular follow up.

10) Follow up: - Follow up of patients of both the groups were taken for observation on $30^{\text {th }}, 60^{\text {th }}$ and $90^{\text {th }}$ day. Observational parameters including prabhootamutrata, aavilmutrata, Naktamutrata were recorded each and every follow up. Then relief of signs and symptoms of both groups were compared with each other.

\section{1) Parameters for Assessment: -}

Assessment of signs and symptoms were done by adapting suitable scoring method.

1] Prabhoota Mutrata:

2] Aavilmutrata:

3] Naktamutrata:

4] Swedatipravritti:

5] Hasta-pada-tala-daha
6] Pipilika sanchar

7] Lab investigation:

- BSL- Fasting and Post Prandial

- HbA1c

Observation and results:

Table: Changes in HbA1C before and after treatment

\begin{tabular}{|l|l|l|l|l|}
\hline Sr.No. & Group & \multicolumn{3}{|l|}{ HbA1C } \\
\cline { 3 - 5 } & & $\begin{array}{l}\text { Mean } \\
\text { BT }\end{array}$ & $\begin{array}{l}\text { Mean } \\
\text { AT }\end{array}$ & Diff. \\
\hline $\mathbf{1}$ & $\begin{array}{l}\text { Group } \\
\text { A }\end{array}$ & 7.68 & 7.32 & 0.36 \\
\hline $\mathbf{2}$ & $\begin{array}{l}\text { Group } \\
\text { B }\end{array}$ & 7.59 & 6.91 & 0.68 \\
\hline
\end{tabular}

- It was observed that average decrease in $\mathrm{HbA} 1 \mathrm{C}$ is more in Trial Group (B) as compared to Control Group (A).

- Table: \% Relief in Symptoms of Group A \& Group B

\begin{tabular}{|c|c|c|c|}
\hline \multirow{2}{*}{$\begin{array}{l}\text { Sr. } \\
\text { No. }\end{array}$} & \multirow[t]{2}{*}{ Symptoms } & \multicolumn{2}{|c|}{ \% Relief } \\
\hline & & $\begin{array}{l}\text { Group } \\
\text { A }\end{array}$ & $\begin{array}{l}\text { Group } \\
\text { B }\end{array}$ \\
\hline 1 & Prabhuta mutrata & 42.86 & 84.62 \\
\hline 2 & Avil mutrata & 46.88 & 75.86 \\
\hline 3 & Nakta mutrata & 61.76 & 83.33 \\
\hline 4 & $\begin{array}{l}\text { Sweda ati } \\
\text { pravartan }\end{array}$ & 50.00 & 100.0 \\
\hline 5 & $\begin{array}{l}\text { Hat pada tala } \\
\text { daha }\end{array}$ & 83.33 & 80.00 \\
\hline 6 & Pipilika sanchar & 66.67 & 91.67 \\
\hline 7 & Average \% Relief & 58.58 & 85.91 \\
\hline
\end{tabular}


Table: Avg. decrease in $\mathrm{HbA} 1 \mathrm{C}$ in both Groups

\begin{tabular}{|l|l|l|}
\hline Sr. & Parameters & Avg. Change \\
\hline
\end{tabular}

\begin{tabular}{|l|l|l|l|}
\hline No. & & $\begin{array}{l}\text { Group } \\
\text { A }\end{array}$ & Group B \\
\hline $\mathbf{1}$ & HbA1C & 0.36 & 0.68 \\
\hline
\end{tabular}

Table: Overall Effect of Therapy according \% Relief

\begin{tabular}{|l|l|l|l|l|l|l|}
\hline Sr. & Criteria & Improvement & \multicolumn{2}{l|}{ No. of patients } & \multicolumn{2}{l|}{ No.of symptoms } \\
\cline { 4 - 7 } No. & & Grade & Gr. A & Gr. B & Gr. A & Gr. B \\
\hline $\mathbf{1}$ & $\mathbf{7 5 \%}$ to $\mathbf{1 0 0 \%}$ & Marked & 00 & 15 & 01 & 06 \\
\hline $\mathbf{2}$ & $\mathbf{5 0 \%}$ to $\mathbf{7 4 \%}$ & Moderate & 13 & 01 & 03 & 00 \\
\hline $\mathbf{3}$ & $\mathbf{2 5 \%}$ to $\mathbf{4 9 \%}$ & Mild & 03 & 00 & 02 & 00 \\
\hline $\mathbf{4}$ & $\mathbf{0 0 \%}$ to $\mathbf{2 4 \%}$ & Poor & 00 & 00 & 00 & 00 \\
\hline
\end{tabular}

- According to statistical analysis

Table: Overall Effect of Therapy Statistical analysis (Subjective)

\begin{tabular}{|l|l|l|l|l|}
\hline \multirow{2}{*}{$\begin{array}{l}\text { No. } \\
\text { No. }\end{array}$} & Subjective Parameters & \multicolumn{2}{|l|}{$\begin{array}{l}\text { Within Groups } \\
\text { (Wilcoxon test) }\end{array}$} & $\begin{array}{l}\text { Comparison } \\
\text { (Mann-Whitney's test) }\end{array}$ \\
\cline { 3 - 4 } & & Group A & Group B & \\
\hline $\mathbf{1}$ & P. mutrata & Significant & Significant & Significant (B > A) \\
\hline $\mathbf{2}$ & A. mutrata & Significant & Significant & Significant (B > A) \\
\hline $\mathbf{3}$ & N. mutrata & Significant & Significant & Insignificant $(\mathrm{A} \approx \mathrm{B})$ \\
\hline $\mathbf{4}$ & Swedaatipravritti & Significant & Significant & Significant $(\mathrm{B}>\mathrm{A})$ \\
\hline $\mathbf{5}$ & Hat pada daha & Significant & Significant & Insignificant $(\mathrm{A} \approx \mathrm{B})$ \\
\hline $\mathbf{6}$ & Pipilika sanchar & Significant & Significant & Insignificant $(\mathrm{A} \approx \mathrm{B})$ \\
\hline
\end{tabular}

( $\approx$ - means statistically equal, not exact equal)

- Table: Overall Effect of Therapy Statistical analysis (Objective)

\begin{tabular}{|c|c|c|c|c|}
\hline \multirow[t]{2}{*}{$\begin{array}{l}\text { Sr. } \\
\text { No. }\end{array}$} & \multirow[t]{2}{*}{ Objective Parameter } & \multicolumn{2}{|c|}{$\begin{array}{l}\text { Within Groups } \\
\text { (Paired t test) }\end{array}$} & \multirow{2}{*}{$\begin{array}{l}\text { Comparison } \\
\text { (Unpaired t } \\
\text { test) }\end{array}$} \\
\hline & & Group A & Group B & \\
\hline 1 & HbA1C & Significant & Significant & Significant $(\mathrm{B}>\mathrm{A})$ \\
\hline
\end{tabular}




\section{Discussion on Results:}

The parameters of Madhumeha were statistically analyzed. Significance of difference between before and after treatment was assessed by applying student's 't ' test for unpaired data of objective parameters like HbA1c. The Wilcoxon test was applied to compare the effect of both treatments. In case of all the parameters, the statistical evaluation revealed that there was significant reduction in sign and symptoms, hence both the treatment were significantly effective in case of Madhumeha. When Wilcoxon test was applied to compare the effect of both treatment, it showed that in case of prabhoot mutrata, aavilmutrata, naktamutrata the treatment of trial group was significantly superior than that of control group. When unpaired ' $t$ ' test was applied to compare the effect of both the treatment, it showed that in case of BSL the treatment of trial group was significantly superior to control group. Effect on prabhoot mutrata, aavilmutrata, naktamutrata was due to kledaghna, kaphaghna, laghu, ruksha property and Kashaya, Tikta rasa Pradhan. In this study it was observed that the patients having mild to moderate signs and symptoms were get cured and those having moderate to severe symptoms were improved.

\section{Trial group:}

Improvement i.e. controlled diseased condition was found in trial group was 93.75\% marked improvement was observed, and $6.25 \%$ moderate improvement was observed.

\section{Control group:}

7 | Nov- 2020 | Vol. 08 ${ }^{\text {th }} \mid$ Issue: $6^{\text {th }}$
Improvement i.e. controlled diseased condition was found in control group was $81.25 \%$ moderate improvement was observed, and $18.75 \%$ mild improvement was observed.

\section{Conclusion:}

- After analyzing the all data and observations, it was concluded that Kaidarya patra choorna used in trial group along with the oral hypoglycemic agents ( Metformin + Sulphonyl Urea group) shown significant results as compared to only oral hypoglycemic agents ( Metformin + Sulphonyl Urea group) used in control group.

- Statistically significant effect of Kaidarya patra choorna on prabhoot mutrata, aavilmutrata and on BSL as compared to control group was may be due to-

- Correction of dushya kleda- utpatti which is responsible for above said lakshana's in samprapti

- The drug also may act at mulasthana of mutravaha strotas which are meda/vapavahan.

- Further it has been concluded that combined therapy is superior and also has organ protective (hepato protective) effect. So for long term use combined therapy is recommended, since kaidarya is swasthavrittakar dravya is safe to take for longer duration in prescribed dose.

\section{References:}

1] Charaka Samhita of Agnivesha elaborated by Charaka and Drudhbala Purvardha and 
Uttarardha, Dr, Bramhanand Tripathi, Choukhamba surbharti Prakashan, Varanasi 2001 Edition.

2] Charaka Samhita with the AyurvedaDipika commentary of Chakrapanidatta Edited by Vaidya Yadavji Trikamji Acharya, Choukhamba Sanskrit Sansthan, $5^{\text {th }}$ Edition.

3] Sushruta Samhita of Sushruta with the Nibandhasangraha Commentary of Dalhanacharya and the Nyaychandrika panika of Shri Gayadasacharya on Nidanasthana, $5^{\text {th }}$ edition Choukhamba oriettalia, Varanasi.

4] Ashtanghridaya composed by Vagbhata with the commentaries of Sarvangasundara of Arunadatta and Ayurvedrasayana of Hemadri by Krishnadas Academy 1995, Choukhamba Prakashana, Varanasi.

5] Prof. K.R. Srikantha Murthy, Ashtang Samgraha of Vagbhata, Uttartantra, chapter 6,verse no.2, page 58 .

6] Sharangdhara Samhita of Sharangdhara containing Anjanidana of Maharshi Agnivesha with Dipika Commentary by Bramhanand Tripathi, 2004 edition, Choukhamba Prakashana, Varanasi.

7] Madhavanidanam 1 and 2 of Madhavakara with the Sanskrit commentary Madhukosha, 2007 edition by Bramhanand Tripathi, Choukhamba Prakashana, Varanasi.

8] Bhavaprakash Nighantu of Shri Bhavamishra Commentary by Dr. K.C.Chunekar edited by Dr.G.S.Pandey,
2004 edition, Choukhamba Prakashana, Varanasi.

9] Dravyaguna Vigyana volume $2^{\text {nd, }} 16$ th edition 1994 by Prof.RV Sharma, Choukhamba Bharati Academy, Varanasi.

10] Bhel Samhita, Shri Girijadaya Shukla, Edition 2006, Choukhamba Bharati Academy, Varanasi.

11] Harita Samhita, edition 1984, Kshemraja -Shrikrishnadas, Shri Iyenktheshwar Prakashana.

12] Ayurvedic Pharmacalogy and Therapeutic uses of Medicinal Plants (Dravyaguna Vigyana) Vaidya V.M.Gogte, first English edition, OCT. 2000

13] Ayurved Kriya Sharira, Vd. Ranjit Desai, Baidyanath Ayurved Bhavan.

14] Wealth of India Raw Materials Vol.V, H-K. Prof. M.S.Thacker, Council of scientific and Industrial Research New Delhi-i-959.

15] Methods in Biostatistics - K. Vishweshwara Rao, $2^{\text {nd }}$ edition, 2007. Jaypee.

16] Yogratnakara, Jaykrishna Haridas Gupta, Banaras.

17] Sucheta soma kirupa and R. Kavita. International journal food and nutritional sciences. Jan-Mar 2013

18] Devrajan Shankar, Amanat Ali, Ganapaty Sambandam, Ramakrishna Rao, Clinical Nutrition- an international journal 
devoted in Clinical nutrition and metabolism.

19] Dr. G.D. Desai, Aushadhi Sangraha, chapter no.33 verse no. 7 .

20] Harneet Singh, Manisha Vats and Satish Sardana. International journal of Pharmacognosy and Phytochemical research- 2012.

21] Researchgate.net (January- 2017) the Pharma innovation Journal.

22] King Saud University, women's students- medical studies and sciences section Riyadh.

23] Harish K. Handral, Anup Pandith and Shruti S.D. ( Asian journal of pharmaceutical and clinical research vol.5 suppl 4 , 2012)

24] Acharya Vishwanath Dwiwedi, Rajnighantu, Krishnadas akadami, Varanasi, page No. 266.

25] The Ayurvedic Pharmacopoeia of India, Part-1 volume 6, first edition, page no. 179.
26] Satish Chand Saini, Dr.GBS ReddyAcute Toxicity study of Murraya koenigii linn. Against Swiss Albino Mice (gujrat).

27] Dr. Sumedh wasnik and Dr. Tanuja Naik (PMT Ayu. Col. Shevgaon) International journal of developmental research (april2016)

28] Acharya Radha Krishna parashar, Sharangdhar Samhita, Baidyanath publication, page no. 247.

29] Harrison's Manual of Medicine, $18^{\text {th }}$ edition, page no. 1137, 1144 .

30] Brian R. Walker, Nicki R. Colledge, Stuart H. Raltson, Ian D. PenmanDavidson's Principles and Practice of Medicine, $22^{\text {nd }}$ edition.

31] G.K.Garde Sartha vagbhata, nidansthana, chapter no.10, verse no.7

32] Acharya Vishwanath Dwiwedi, Rajnighantu, krushnadas akadami, Varanasi, page no.266

33] www.researchgate.net

Conflict of Interest: Non

Source of funding: Nil

\section{Cite this article:}

Hypoglycemic activity of Kaidarya Patra Choorna (Murraya koenigii linn.)

in Diabetes mellitus type 2 with OHA's

Rawate Suraj M. , Kore Sharayu

Ayurlog: National Journal of Research in Ayurved Science- 2020; (8) (6):01- 09 